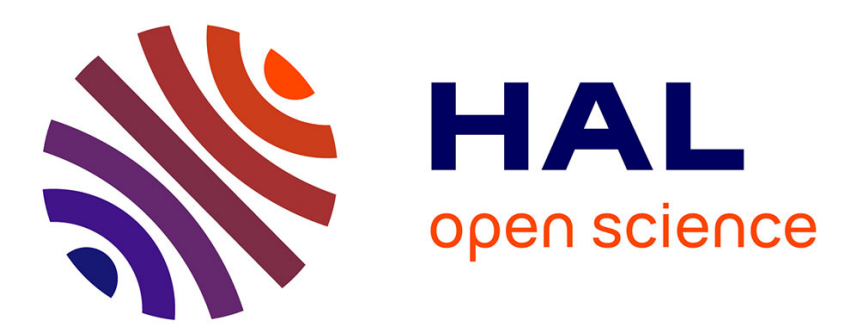

\title{
Human- and climate-driven shoreline changes on a remote mountainous tropical Pacific Island: Tubuai, French Polynesia
}

\author{
Camille Salmon, Virginie K.E. Duvat, Victoire Laurent
}

\section{To cite this version:}

Camille Salmon, Virginie K.E. Duvat, Victoire Laurent. Human- and climate-driven shoreline changes on a remote mountainous tropical Pacific Island: Tubuai, French Polynesia. Anthropocene Review, 2019, 25, pp.100191. 10.1016/j.ancene.2019.100191 . hal-02004700

\author{
HAL Id: hal-02004700 \\ https://hal.science/hal-02004700
}

Submitted on 21 Oct 2021

HAL is a multi-disciplinary open access archive for the deposit and dissemination of scientific research documents, whether they are published or not. The documents may come from teaching and research institutions in France or abroad, or from public or private research centers.
L'archive ouverte pluridisciplinaire HAL, est destinée au dépôt et à la diffusion de documents scientifiques de niveau recherche, publiés ou non, émanant des établissements d'enseignement et de recherche français ou étrangers, des laboratoires publics ou privés.

\section{(ㄷ)(1) $\$$}

Distributed under a Creative Commons Attribution - NonCommerciall 4.0 International 


\section{Human- and climate-driven shoreline changes on a remote mountainous 2 tropical Pacific Island: Tubuai, French Polynesia}

3 Camille SALMON $^{\mathrm{a}^{*}}$, Virginie K.E. DUVAT ${ }^{\mathrm{a}}$, Victoire Laurent ${ }^{\mathrm{b}}$

4

$5 \quad{ }^{a}$ UMR LIENSs 7266, Université de la Rochelle-CNRS, 2 rue Olympe de Gouges, 17000 La Rochelle, France

$6 \quad$ birection Inter Régionale de Polynésie Française, Météo France, 98702 Tahiti, French Polynesia

$7 \quad{ }^{*}$ Corresponding author.

8 E-mail address: camille.salmon@univ-lr.fr

9

\section{Acknowledgments}

11 This work was supported by the French Ministry of Environment, Energy and Oceans 12 (MEEM) in the framework of the "Risque, Décision, Territoire" programme (No. 13-MRES13 RDT-1-CVS-022, 2013-2016), and by the French National Research Agency under the 14 STORISK research project (No.ANR-15-CE03-0003). The authors also acknowledge support 15 from the Government of French Polynesia, especially the Topography Section of the Town 16 Planning Division, and from the National Centre for Spatial Studies (CNES, Centre National 17 d'Études Spatiales) for providing historical aerial photographs and Pléiades satellite imagery, 18 respectively. Additionally, the authors are grateful to Melanie Becker, Sophie Lecacheux and 19 Samuel Etienne, for providing sea-level data, wave height maps and post-Oli aerial 20 photographs, respectively. The authors also thank Toanui Viriamu for the highly-valuable 21 data collected on Tubuai through semi-structured interviews with locals during his Master 22 degree's internship in 2017, and Aldabra Magnan for help in the coastal defence structure 23 assessment that was conducted in 2013. 


\title{
Human- and climate-driven shoreline changes on a remote mountainous tropical Pacific Island: Tubuai, French Polynesia
}

\begin{abstract}
Few studies have focused on shoreline change on high mountainous tropical islands, whereas their low-lying coastal areas generally host most population centres and human assets. This paper contributes filling this gap by assessing shoreline change on a remote Pacific island, Tubuai, French Polynesia. Different shoreline proxies and time periods are considered, based on the 32-year available aerial imagery (1982-2014). Over the multi-decadal timescale, the base of the beach predominantly exhibited retreat, which was observed along $57 \%$ of the shoreline. The stability line, which consists either of the vegetation line, or of the base of coastal defences, depending on shoreline sections, was found to be more resistant to coastal erosion, as $61 \%$ of the shoreline remained stable while $32 \%$ experienced retreat. At shorter timescales (i.e. for the four sub-periods considered in this study), our results show high spatial-temporal variability. Investigating the respective contributions of human activities and intense tropical cyclones to shoreline change, we found that the former had a major influence despite low population density, while the latter had a moderate influence. In fact, human disturbances have extensively destabilized sediment cells, which is likely to exacerbate the negative impacts of future cyclones on both these systems and the human society. This case study is particularly interesting to address risk reduction strategies in remote island contexts, i.e. with low population densities and available space.
\end{abstract}

Keywords: shoreline change, tropical cyclones, anthropogenic disturbances, Tubuai Island, French Polynesia, Pacific Ocean 


\section{Introduction}

Small tropical islands are considered particularly vulnerable to coastal hazards due to their morphological and human characteristics, especially their small size, remoteness, high population pressure on ecosystems and natural resources, and concentration of most human assets in low-lying coastal areas (Pelling and Uitto, 2001; Nurse et al., 2014; Scandurra et al., 2018). Climate-related coastal risks, which involve shoreline retreat and marine inundation, are caused by both extreme episodic events, such as distant-source swells and tropical cyclones (TCs), and gradual changes, such as mean sea-level rise (Nurse et al., 2014; Ranasinghe, 2016; Duvat et al., 2017a). Moreover, these risks are expected to increase, as mean sea-level rise is accelerating (Ranasinghe, 2016). In order to better estimate the past-topresent and future trajectories of change of island shorelines, and design relevant adaptation strategies, baseline scientific information, such as event-induced and multi-decadal shoreline changes, is needed (Hapke et al., 2013; Duvat et al., 2017a). Appreciating shoreline positional change (including the rate and spatial variability of change) and its drivers thus constitute highly valuable information for coastal planning and risk management (Romine and Fletcher, 2012a; Duvat et al., 2017b). This need was notably illustrated at the global scale by the pioneer review carried out by Bird (1985) and, very recently, by the beach erosion assessment conducted by Luijendijk et al. (2018). Beyond these global assessments, numerous regional or local studies have been conducted during the last decades, but concerning small islands, we observe significant gaps according to their type and to their geographical extent.

Indeed, since the pioneer study on atoll island planform changes by Webb and Kench (2010), the persistence of atoll islands over the 21 st century has raised major attention, as indicated by the increasing number of publications on this concern (Kench and Mann, 2017; Duvat, 2018). On the other hand, high tropical islands from volcanic or continental origin were not subject to such scientific efforts, whereas their low-lying coastal areas generally host most population centres and human assets, including critical infrastructure (De Scally, 2014; Nurse et al., 2014). Yet, if these coastal plains constitute less vulnerable geomorphic features than lowlying atoll islands, because they are stable in position, generally large, and supplied with sediments by both the reef ecosystem and rivers, they also are affected by coastal erosion, as shown by Romine and Fletcher (2012a) for Hawaii, by Bheero et al. (2016) and Duvat et al. (2016) respectively for Mauritius and Reunion Island, and by Jackson et al. (2012) for Puerto Rico. To our knowledge, these islands are the only high tropical islands for which peerreviewed shoreline change studies are available. Although these studies brought significant insights for shoreline change understanding in high islands, their number and spatial extent remain limited. Yet, documenting a large number of islands, according to their types (from low-lying atoll islands to high mountainous islands, from urban to rural, from different areas and political contexts), is crucial to reveal the diversity of existing storylines (including both morphological change and human development) so as to be able to design context-specific solutions to coastal risks (Nunn et al., 2016). In particular, it seems crucial, beyond considering densely-populated capital islands that constitute key hotspots of risks, to also address the situation of rural islands, because they also face important challenges regarding coastal risks and climate change (Duvat et al., 2017a).

This paper addresses this gap by studying shoreline change on the northern coast of Tubuai Island, a remote island located in the Austral Archipelago in French Polynesia (Central Pacific Ocean). Interestingly, Tubuai provides a good example of a territory showing a high- 
level of exposure of people and human assets to coastal hazards despite a low population density, due to the concentration of the population and human assets within a $200 \mathrm{~m}$-wide coastal strip around the island's perimeter. This case study thus brings key insights to rethink risk reduction and adaptation to climate change strategies in remote and rural high tropical islands.

Based on photo-interpretation from available aerial imagery and fieldwork, this study aimed to assess the contribution of anthropogenic and climatic drivers to shoreline change. First, we analysed shoreline change at different time periods, including multi-decadal (1982-2014) and event-related (i.e. cyclonic), using the base of the beach and the stability line as shoreline proxies (Romine and Fletcher, 2012b; Duvat and Pillet, 2017; Duvat et al., 2017b). Second, we investigated the contribution of human activities to shoreline change and beach systems' destabilization, in line with previous studies (e.g. Cooper and Pilkey, 2012; Jackson et al., 2012; Romine and Fletcher, 2012b). In doing so, we assessed the role of land reclamation, the interception of the longshore sediment drift by transversal structures (wharves, harbours, groynes), and shoreline armouring. Finally, we investigated the contribution of one specific climate-related driver of change, tropical cyclones (TCs) or tropical depressions (TDs). The fact that three significant events struck the island during the study period (with TC Oli in 2010 being the most intense TC ever recorded in the Austral Archipelago) made it possible to analyse their contribution to shoreline positional change.

\section{Setting}

The Austral Archipelago, which is one of the five archipelagos composing French Polynesia, consists of five main high volcanic or limestone islands, and of one atoll. Tubuai Island, which is located $640 \mathrm{~km}$ south to Tahiti Island (Fig. 1), is both the largest and the capital island of the Archipelago, and comprised 2,322 inhabitants in $2017^{1}$. It is a high volcanic island of $45 \mathrm{~km}^{2}$ encircled by a barrier reef and a large lagoon covering $94 \mathrm{~km}^{2}$ (Fig. 2A). Mount Taita'a is the highest point of the island, reaching $422 \mathrm{~m}$ in elevation. A large coastal plain exhibiting small rivers and swampy areas has formed around the inner mountainous relief. Most inhabitants live in Mataura (970 inhab.) and Taahuaia (645 inhab.) villages, which are located on the northern and north-eastern coasts, respectively (Fig. 2B). The rest of the population of the island lives either in Mahu (602 inhab.), which is the main village on the southern coast, or in hamlets and isolated houses scattered throughout the island. Tubuai is thus a rural island with a low population density of $\sim 48$ inhabitants $/ \mathrm{km}^{2}$. However, most of the population and human activities and infrastructures concentrate within a $200 \mathrm{~m}$-wide coastal strip, since the main road (and later on, water and electric facilities) was constructed very close to the shoreline all along the island contour. Tubuai's coast consists of narrow (generally <10 m-wide) sandy barrier beaches, interrupted by river mouths in places (Fig. 2B). The coastal vegetation is mainly composed of shrubs (Crinum asiaticum, Scaevola taccada) and trees, with Casuarina equisetifolia being the dominant tree species, especially in highly-modified coastal areas. Of note, a fringing reef occurs along the northern coast of the island, which therefore presents the specificity of having both a fringing and a barrier reef.

\footnotetext{
${ }^{1}$ Sources: http://www.ispf.pf/bases/Recensements/Historique/Donnesdtailles.aspx https://www.insee.fr/fr/statistiques/3294364?sommaire=2122700
} 
Trade-wind swells, mainly originating from the south-east, have a height comprised between 2 and $4 \mathrm{~m}$, and an average period of $10 \mathrm{~s}$. In addition, Tubuai lies in the area exhibiting the strongest non-cyclonic heavy swells in French Polynesia. The depressions sailing eastward far south of French Polynesia during the austral winter generate long and powerful swells coming mainly from the south-west to the south, with periods greater than or equal to $12 \mathrm{~s}$ and a height exceeding $4 \mathrm{~m}$. These distant-source swells mainly affect the southern coast of the island. In addition to these wind-wave regimes, Tubuai is affected by cyclonic waves mainly originating from the north-west to the north-east (cf. section 3.2.2.), and therefore mainly affecting its northern coast.

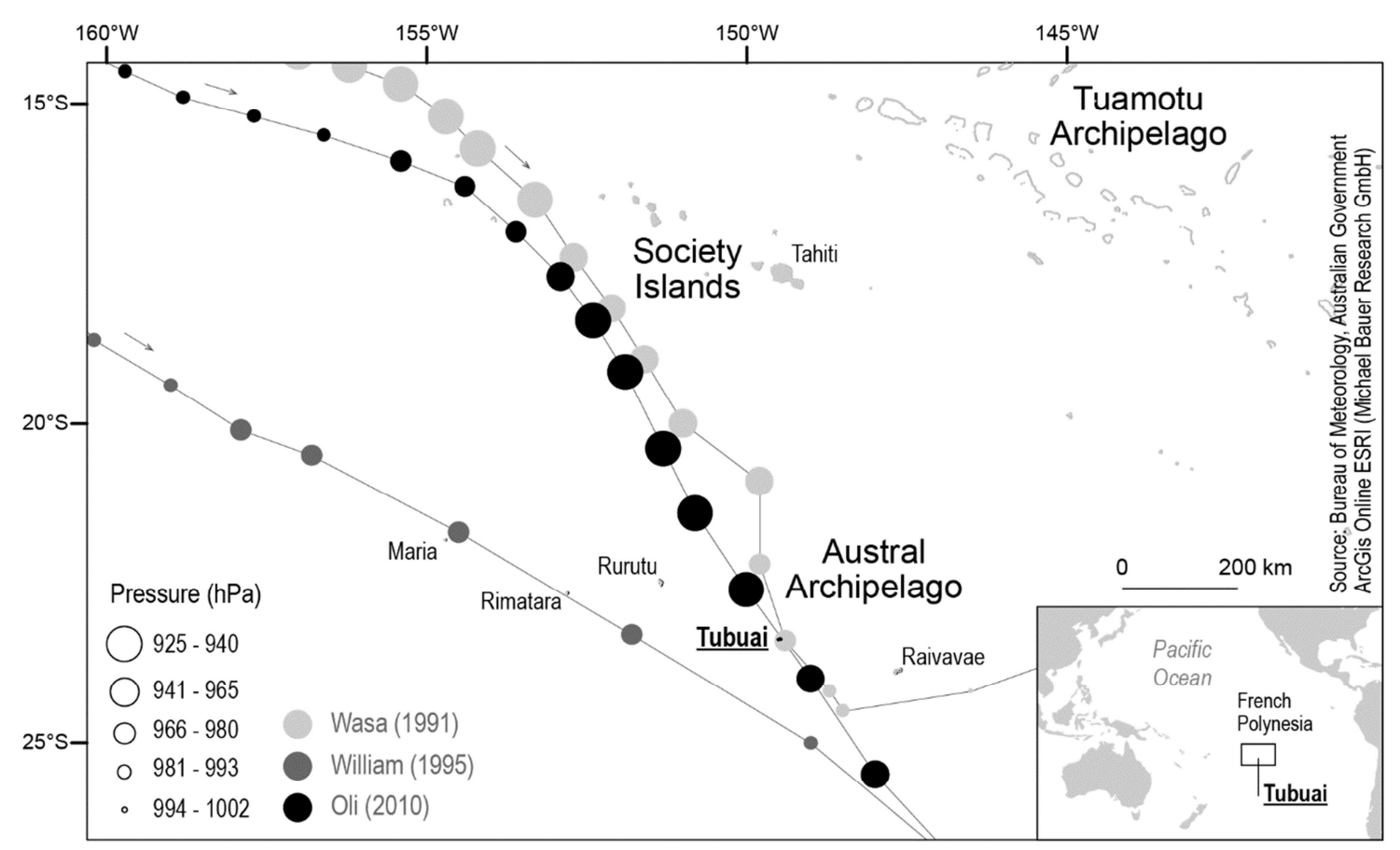

Fig. 1. Location map of Tubuai Island in French Polynesia (Pacific Ocean) and tracks of the tropical cyclones considered in this study (cf. section 3.2.2.). Source: http://www.bom.gov.au/cyclone/history/tracks/index.shtml

Tubuai is schematically composed of one main sediment cell ${ }^{2}$. The prevailing westerly longshore sediment transport is driven by the trade-wind waves. However, local reversals of the longshore sediment drift occur, due to the presence of several passes in the barrier reef, which generate strong discharge lagoon-to-ocean currents. Moreover, transversal humanmade structures (e.g. wharves, harbour, groynes) obstruct the longshore sediment drift, thereby disrupting the natural east-west oriented sediment transfer and fragmenting the main sediment cell into sub-cells (Fig. 2B). The tidal range is low, with a neap range of $\sim 0.2 \mathrm{~m}$ and a spring range of $\sim 0.8 \mathrm{~m}$ (Van Wynsberge et al., 2017). Past sea-level reconstructions over the 1960-2012 period indicate for Tubuai a sea-level rise of 2.5+/-0.2 mm/y (Meyssignac et al., 2012).

\footnotetext{
${ }^{2}$ A sediment cell (or littoral cell) is a "coastal compartment that contains a complete cycle of sedimentation including sources, transport paths, and sinks. The cell boundaries delineate the geographical area within which the budget is balanced, providing the framework for the quantitative analysis of coastal erosion and accretion." (Inman, 2005). A sediment cell can be subdivided into smaller cells (i.e. sub-cells), as on Tubuai Island.
} 

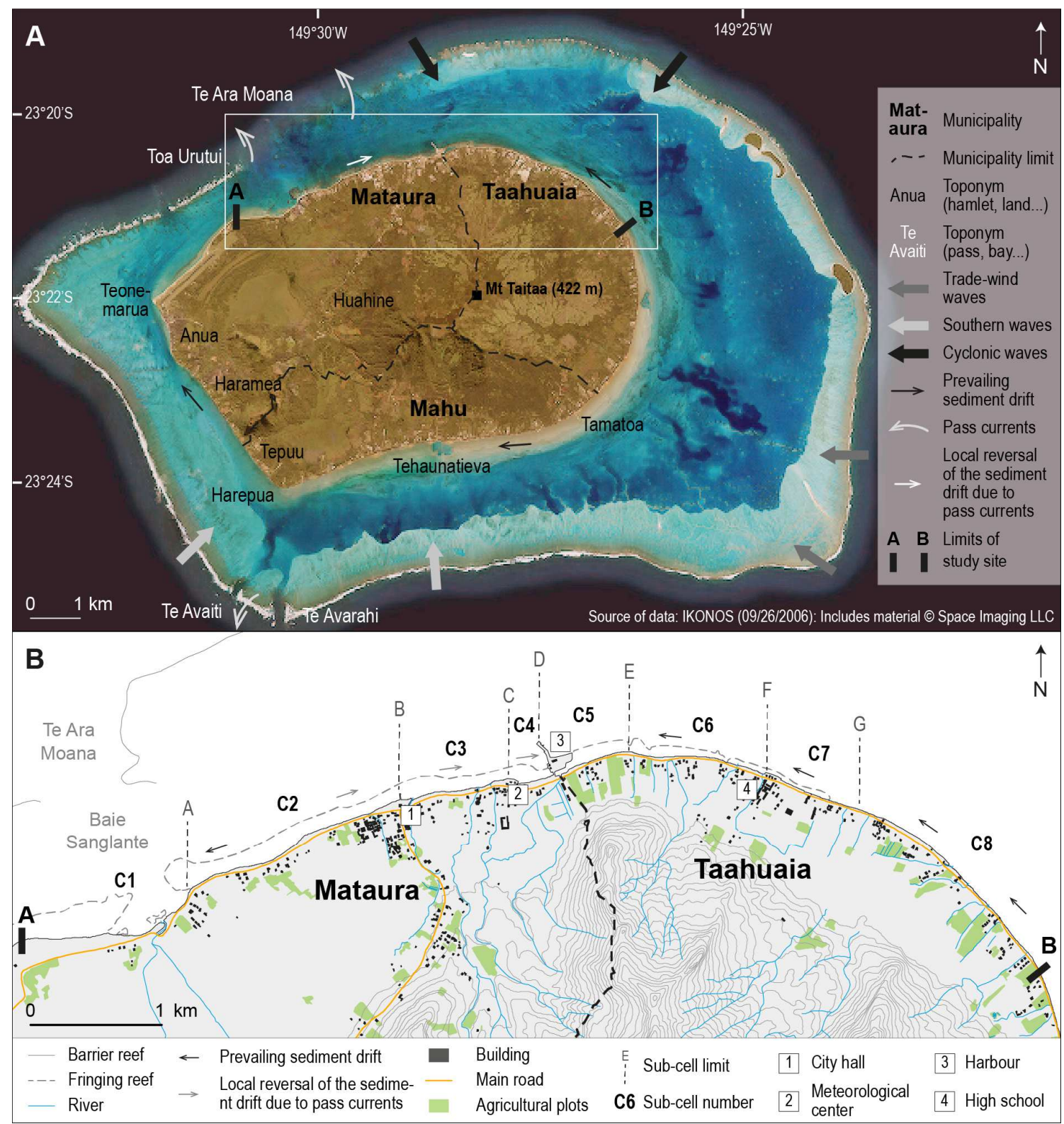

Fig. 2. A) Map of Tubuai Island and location of the study area on the northern coast. Of note, this coast is the most exposed to tropical cyclones and the most urbanized of the island. Arrows showing the currents are based on observations from aerial imagery and fieldwork. B) Focus on the study area, which extends along approximately $9 \mathrm{~km}$ of shoreline, and includes Mataura and Taahuaia municipalities, from the 'Baie Sanglante' to the eastern coast of Taahuaia. It is divided into eight sediment sub-cells (cf. section 3.2.1.). The main public infrastructures are indicated by numbers 1-4 and can be used as landmarks (city hall, high school, etc.). Map data: Ikonos satellite imagery (CDigitalGlobe 2006), Town Planning Division of the Government of French Polynesia.

\section{Material and Methods}

The approach is composed of two main steps: 1) assessing shoreline positional changes at different time periods (from the multi-decadal to the event scale); and 2) investigating the contribution of human activities and cyclonic events. These steps are based on multi-temporal 
image analysis, completed with field observations conducted between 2013 and 2017. Both historic aerial photographs and satellite imagery were used (Table 1) as a source of information to digitize shoreline position. The different time periods used are presented in Fig. 3. Details on georeferencing are provided in Supplementary Material (see SM section 1.1.).

Table 1

Characteristics of the aerial and satellite imagery used in this study.

\begin{tabular}{cccc}
\hline Date & Image type & Scale & Pixel size $(\mathrm{m})$ \\
\hline $01 / 20 / 1982$ & B/W aerial & $1: 10,000 / 1: 25,000$ & \\
$01 / 24 / 1993$ & B/W aerial & $1: 10,000$ & 1 \\
$09 / 26 / 2006$ & Ikonos & & 0.5 \\
$02 / 09 / 2010$ & WorldView2 & & 0.5 \\
$04 / 26 / 2014$ & Pléiades & & \\
\hline
\end{tabular}

\subsection{Assessing shoreline positional changes}

\subsubsection{Shoreline proxies and interpretation}

Two shoreline proxies were used in this study. In line with previous studies (Duvat and Pillet, 2017; Duvat et al., 2017b), the stability line was used as a shoreline proxy indicating the seaward limit of the stabilized part of the coastal system. It was determined by digitizing the edge of the vegetation or the base of coastal structures (seawalls, rip-raps, etc.), depending on the setting (Fig. 4). This was made possible by the exhaustive inventory of coastal structures on the ground, completed with the conduction of surveys among inhabitants, which allowed collecting the date of construction of these structures (see SM section 1.2.). In addition, we digitized a second shoreline proxy, namely the base of the beach, which is relevant for the detection of TCs' impacts (Duvat and Pillet, 2017; Duvat et al., 2017b; Duvat et al., 2017c). This proxy, also called 'toe of the beach' or 'beach step' (Fletcher et al., 1997; Rankey, 2011), corresponds to "an abrupt change in slope and substrate between the unconsolidated beach sediments and the reef flat or lagoon sand bars" (Duvat et al., 2017c). On Tubuai, given the calm hydrodynamic conditions due to the presence of a barrier reef (and also of a fringing reef along the northern coast), the base of the beach was easily detectable on all image series, regardless the stage of the tide (see SM section 1.2.). Transects indicating beach loss were reported in order to analyse this erosional pattern (spatial extent, distribution and temporal change). Where land reclamation occurred, the base of the beach was not included in shoreline change analysis, as doing so would have indicated shoreline advance whereas the beach no longer exists. This explains the 'no data' values in the results presented. 


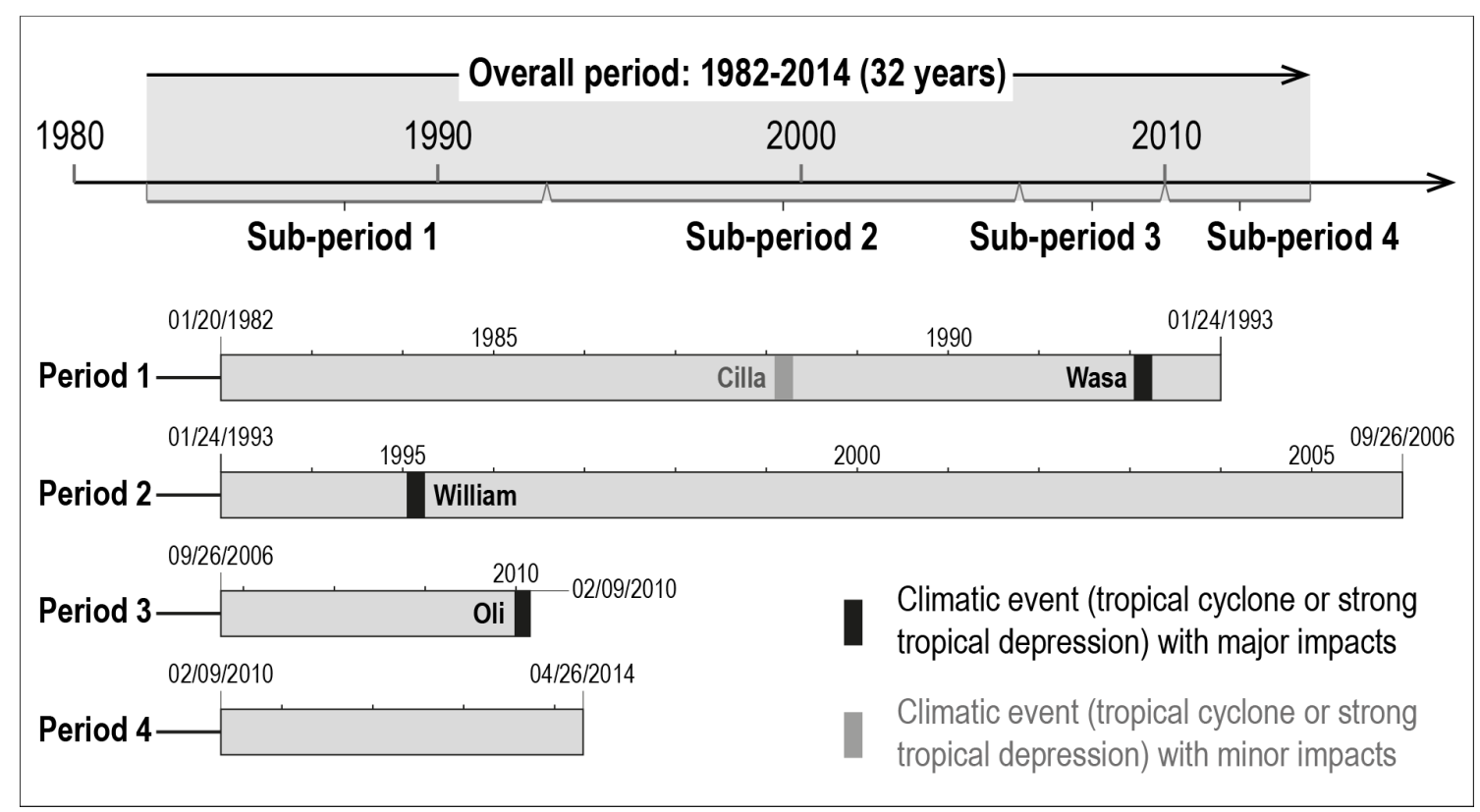

Fig. 3. Summary chart of time periods and of high-energy events considered in this study (cf. section 3.2.2.). The above timeline is a general overview of the overall period (1982-2014) and boundaries of the 4 sub-periods considered. The following timelines present for each sub-period: 1) the temporal boundaries based on image availability; 2) if a climatic event occurred and when. Of note, TC Cilla (1988) was indicated although it did not have impacts on the study coast (Laurent and Varney, 2014). 


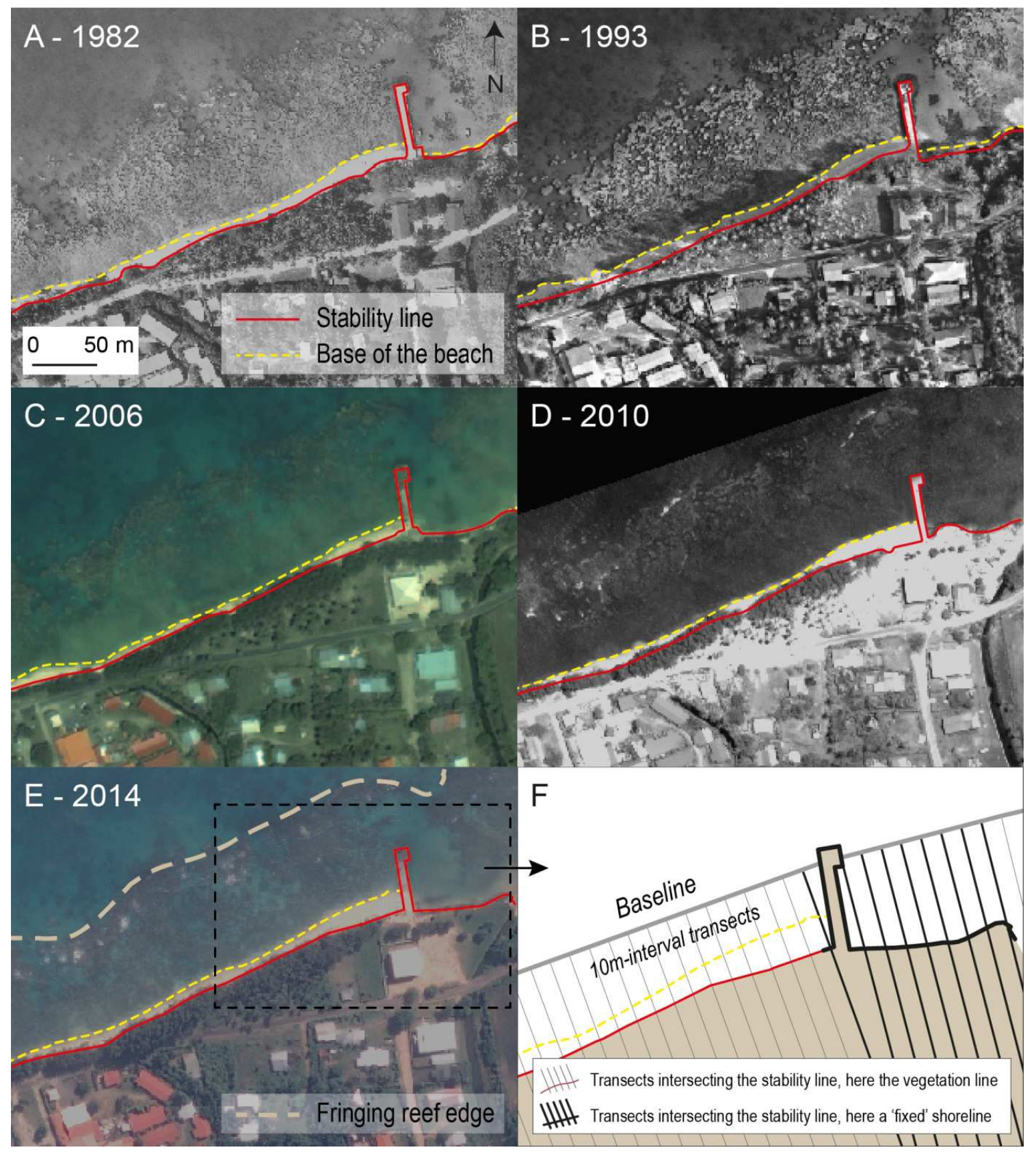

Fig. 4. Illustration of shoreline digitization on the different images used in this study. A) 1982; B) 1993; C) 2006; D) 2010; E) 2014; F) Zoom in on the wharf zone, with 10m-interval transects generated from an offshore baseline. These transects intersect the different shorelines that were created by photo-interpretation (here nature of shoreline, i.e. vegetation line vs. armoured shoreline). Imagery sources: Pléiades satellite imagery (CCNES 2014), Ikonos satellite imagery (CDigitalGlobe 2006), WorldView2 satellite imagery (@DigitalGlobe 2010) and aerial photographs $(1982,1993)$ distributed by the Town Planning Division of the Government of French Polynesia.

\subsubsection{Shoreline change analysis}

Shoreline change were calculated at regular intervals $(10 \mathrm{~m})$ along the shoreline using the Digital Shoreline Analysis System (DSAS) in ArcMap 10.4. The 10m-interval transects were generated from an offshore baseline parallel to the coast (Thieler et al., 2017). As a result, 858 transects were generated and used to measure shoreline change. Two statistic outputs were 
computed for each time period: 1) the Net Shoreline Movement (NSM), which corresponds to the distance in $m$ between two shorelines; 2) the End Point Rate (EPR), which indicates rates of shoreline change in $\mathrm{m} / \mathrm{y}$. In addition to these outputs, the percentage of erosional, stable and accretionary transects was calculated for each time period.

\subsubsection{Shoreline uncertainty assessment}

Uncertainty was calculated for each date, then for each time period (see SM section 1.3.), taking into account the georeferencing error, the resolution error and the digitization error. Of note, the tidal error was considered to be insignificant (see SM section 1.2.), and was not included in the calculation of the total shoreline position error. The georeferencing error was estimated by measuring the distance of perennial landmarks $(\sim 10)$ between the georeferenced image and the Pléiades satellite imagery. As maximum offsets of $3 \mathrm{~m}$ were observed for each pair of images, this value was considered as indicative of the georeferencing error. The resolution error corresponded to the pixel size and ranged from 0.32 to $1 \mathrm{~m}$. In order to estimate the error associated with shoreline digitization, repeated digitization $(\mathrm{N}=3)$ of shoreline proxies in three sample areas (length 100 m) was conducted by the same operator and averaged for each image (using the DSAS transects). The values ranged from 0.99 to 2.48 $\mathrm{m}$. Total shoreline error was calculated as the root sum of all shoreline position errors (Hapke et al., 2006), and ranged from 1.14 to $3.90 \mathrm{~m}$ (SM table 1). Eventually, the root sum of total shoreline errors was calculated to determine the uncertainty for each time period, e.g. 20062010 (SM table 2). Based on this assessment, a unique uncertainty value of $5 \mathrm{~m}$ was obtained. As a result, changes of less than $5 \mathrm{~m}$ were not considered significant and were interpreted as indicating stable shorelines. This value is in accordance with the values obtained in previous studies (e.g. Yates et al., 2013).

\subsection{Investigating the drivers of shoreline change}

\subsubsection{Contribution of human activities}

In small tropical islands, human-induced disturbances caused to coastal dynamics potentially explain shoreline change (Duvat et al., 2017c; Kench and Mann, 2017). By spatially superimposing the former with the latter, we can estimate if the considered disturbance contributes to explaining the observed change. Therefore, the base of coastal defence structures and shoreline sections where land reclamation occurred were digitized, including their first occurrence on aerial images. As a result, obtained data showed first, the spatial extent of these features, and second, their change (i.e. extension vs. reduction in length) over time. In addition, we divided the study area into eight sub-cells, based on the presence of human-made structures obstructing longshore sediment transfer (wharves, harbour, groynes). The characteristics of sub-cell boundaries are described in Fig. 5 and SM section 1.4. Superimposing these limits with shoreline change results enabled estimation of the contribution of these structures to observed change. All these data were combined in the GIS transects layer's attribute table, eventually enabling the cross-analysis of shoreline change and human-disturbance data, and thereby, the determination of the contribution of human disturbances to shoreline change. As a result, each of the 858 transects was documented with the following information: (i) shoreline change results for each time period; (ii) artificial shoreline advance (i.e. due to land reclamation), where occurring; (iii) armoured shoreline; (iv) location of transversal coastal structures (e.g. "transects located updrift a wharf"). In addition, the date of the image where the disturbance was observed for the first time was 
documented. The baseline output consists of the number of transects concerned by land reclamation and shoreline armouring for each period and sub-cell.
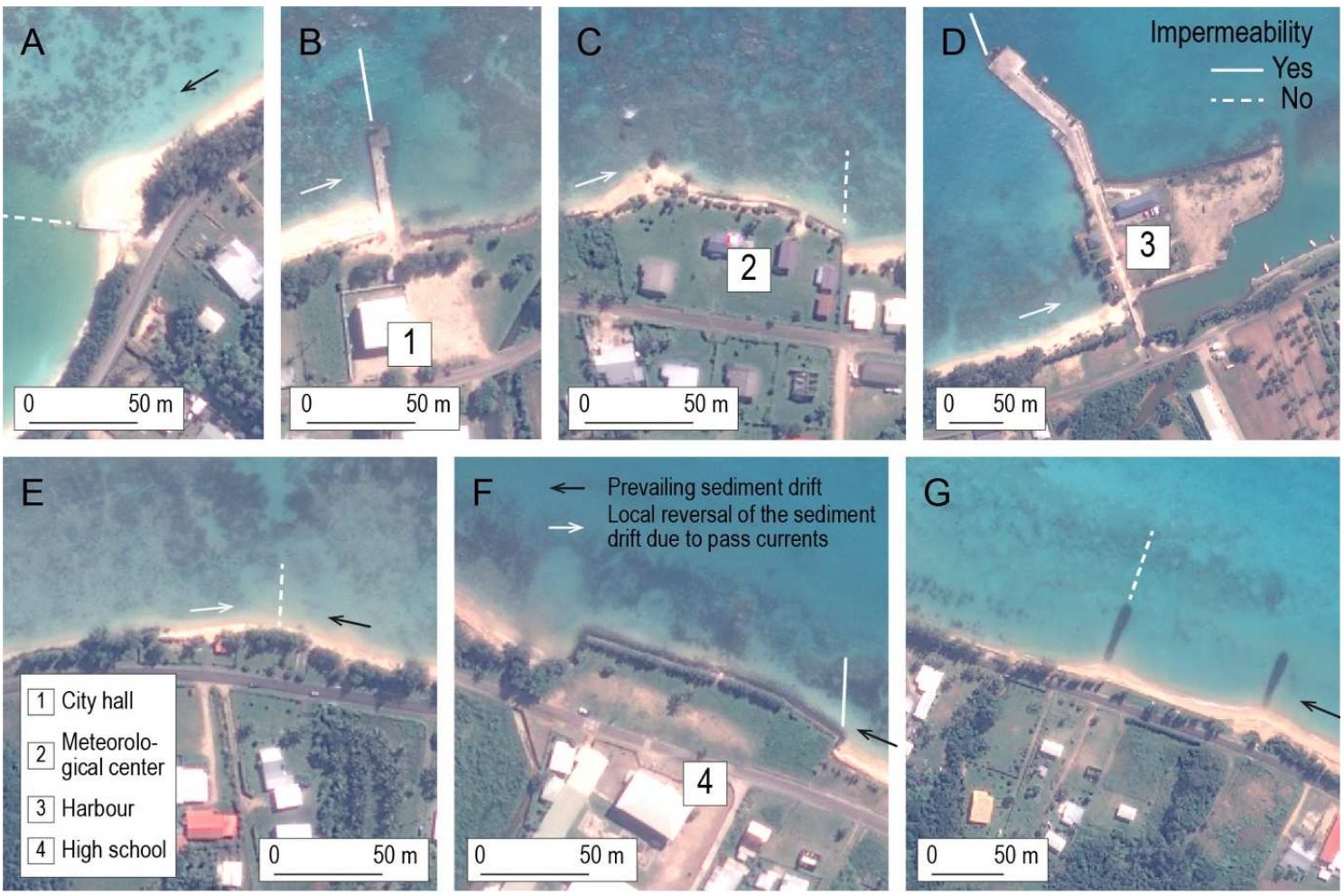

Fig. 5. The boundaries of the eight sub-cells considered in this study and their impermeability. A) Boundary between sub-cell 1 and sub-cell 2; B) Boundary between sub-cell 2 and sub-cell 3; C) Boundary between subcell 3 and sub-cell 4; D) Boundary between sub-cell 4 and sub-cell 5; E) Boundary between sub-cell 5 and subcell 6; F) Boundary between sub-cell 6 and sub-cell 7; G) Boundary between sub-cell 7 and sub-cell 8 . Longshore sediment drift and landmarks shown in Fig. 2B are also indicated. Imagery source: Pléiades satellite imagery (CCNES_2014, Airbus DS Distribution, all rights reserved).

\subsubsection{Contribution of climate-related drivers}

TCs or TDs are widely acknowledged to be key controls of coastal morphology and shoreline change (Duvat and Pillet, 2017; Duvat et al., 2017b, 2017c; Kench and Mann, 2017). In this case, the methods consisted in dividing the overall study period into sub-periods in order to isolate at least one of the three cyclonic events that occurred over the timeframe of analysis. As a result, each time period revealed one specific configuration in terms of cyclonic conditions (with or without a TD or TC), which was used to interpret shoreline change and to address TCs' contribution to shoreline change.

Tropical cyclones considered in this study

Over the study period (1982-2014), three major cyclonic events affected the island: TC Wasa in 1991, TD William in 1993 and TC Oli in 2010 (Figs. 1 and 6, Table 2). Whereas TCs Wasa and Oli directly hit Tubuai from the north, TD William tracked $200 \mathrm{~km}$ to the west and generated lower significant wave height (Fig. 6). TD William however caused important damages, such as the partial destruction of the wharf located near the city hall (cf. landmark 1) (Laurent and Varney, 2014; Viriamu, 2016). TC Oli was the first category 4 TC recorded in the Central Pacific Ocean, and one of the most destructive climate events in French Polynesia, 
causing a total of USD 13 million in damages (Barriot et al., 2016). Significant wave height in the deep ocean reached $14 \mathrm{~m}$ and waves at the coast reached $8 \mathrm{~m}$ (Fig. 6 and Table 2), provoking a storm surge of $\sim 2 \mathrm{~m}$ (Barriot et al., 2016). 


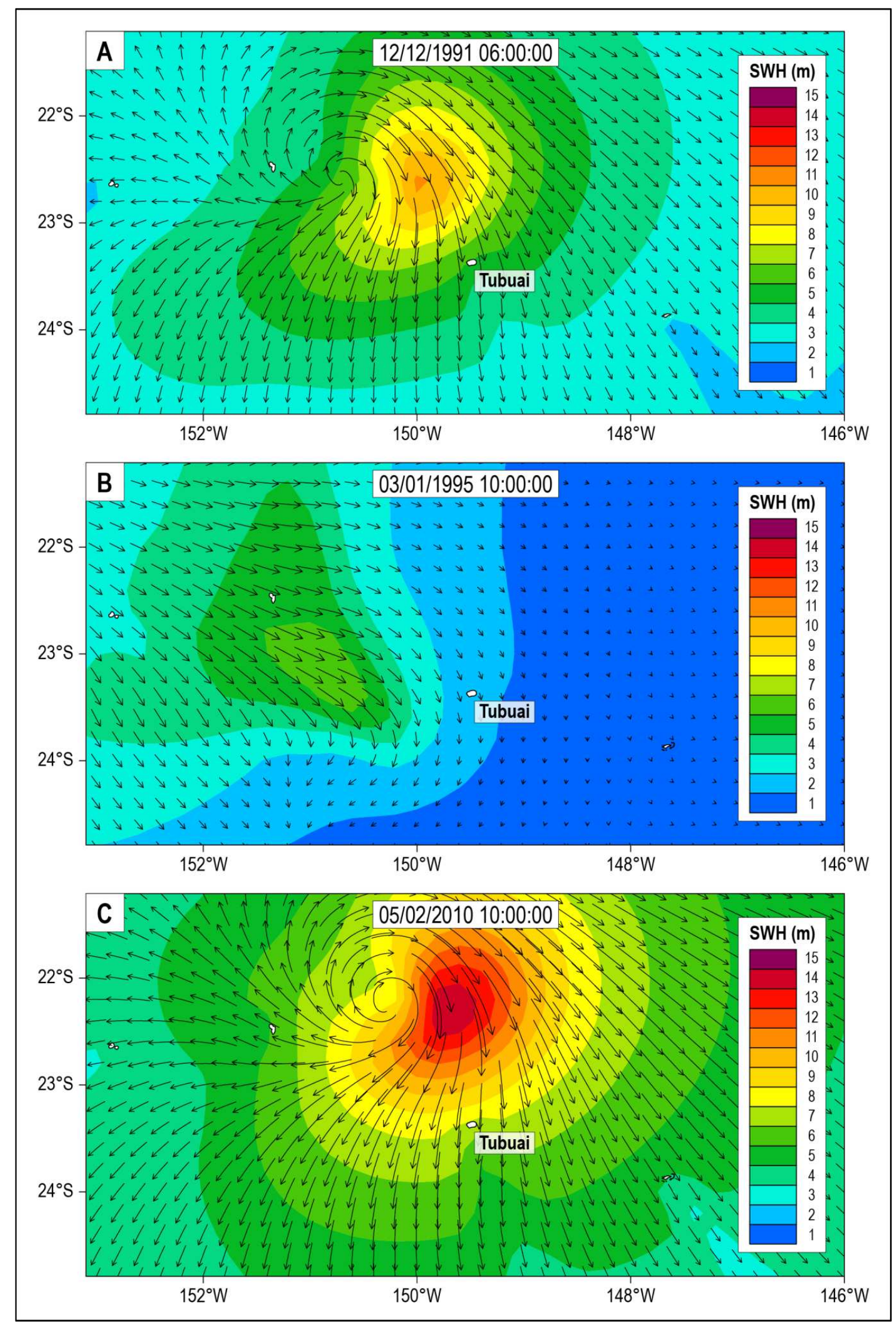


Fig. 6. Significant wave height and wave direction during TC events. A) TC Wasa; B) TD William; C) TC Oli. These data highlight that the northern (and especially the north-eastern) coast is the most exposed to cyclonic waves. They also show how strong TC Oli was (wave data were generated with the WW3 model, see Lecacheux et al., 2013 for further details about the methods).

Table 2

Characteristics of the main tropical depressions and cyclones that hit Tubuai Island over the 1982-2014 period (values in parenthesis specifically refer to Tubuai).

${ }^{\mathrm{a}}$ Data source: Bureau of Meteorology, Australian Government; Laurent and Varney, 2014

${ }^{\mathrm{b}}$ Data source: Laurent and Varney, 2014; Laurent in Salvat et al., 2015

\begin{tabular}{|c|c|c|c|}
\hline $\begin{array}{l}\text { Event, date and category on the } \\
\text { Saffir-Simpson scale }\end{array}$ & $\begin{array}{l}\text { Lowest atmospheric } \\
\text { pressure }^{\mathrm{a}}(\mathrm{hPa})\end{array}$ & $\begin{array}{c}\text { Average wind } \\
\text { velocity }^{\mathrm{a}}(\mathrm{km} / \mathrm{h})\end{array}$ & $\begin{array}{l}\text { Estimated height of } \\
\text { waves at the coast } \mathrm{b}^{\mathrm{b}}(\mathrm{m})\end{array}$ \\
\hline $\begin{array}{c}\text { Wasa } \\
\text { 5-13 December } 1991 \\
\text { Category } 1 \\
\text { (11-12 December 1991 } \\
\text { Tropical depression) }\end{array}$ & $940(975)$ & $180(100)$ & No data \\
\hline $\begin{array}{c}\text { William } \\
30 \text { December 1994-3 January } 1995 \\
\text { Tropical depression } \\
\text { (2-3 January 1995 } \\
\text { Tropical depression) }\end{array}$ & 975 (985) & (115) & No data \\
\hline $\begin{array}{c}\text { Oli } \\
\text { 29 January-8 February } 2010 \\
\text { Category } 4 \\
\text { (4-5 February 2010 } \\
\text { Category 2) }\end{array}$ & 925 (940) & $198(100)$ & $9(6-8)$ \\
\hline
\end{tabular}

Isolating a cyclonic event

Capturing the impacts of historic TCs from multi-date image analysis is challenging, as the optimal configuration implies images to be taken just before (i.e. a few days before) and just after (i.e. a few days after) the studied TC. However, these optimal conditions are rarely fulfilled for tropical islands, for which aerial imagery is scarce. In the Austral Archipelago, although TCs are frequent, few historical vertical aerial photographs are available. Indeed, Tubuai is a remote island with no strategic military role, i.e. no specific role during WWII and no nuclear testing (unlike the Tuamotu Archipelago). As a result, few series of vertical aerial photographs exist, with the oldest series dating back to 1982, followed by the 1993 series. The advent of high-resolution satellite imagery in the 2000s has increased temporal coverage and thus the possibility to isolate a cyclonic event. Ikonos, WorldView2 and Pléiades images taken in 2006, 2010 and 2014, respectively, are available and were therefore used in this study. This material enabled to divide the overall time period into four sub-periods for shoreline change analysis (Fig. 3). Superimposing the dates of occurrence of TCs on these sub-periods enabled to classify available images into two main categories: 1) images exhibiting no signal of a high-energy event (i.e. sub-period with no event occurring, e.g. subperiod 4; or sub-period characterized by an early event, as sub-period 2); 2) images showing the impacts of an event. This is the case, first, for sub-period 3, as the WorldView2 image was taken only five days after TC Oli stroke Tubuai, and, second, and to a lesser degree, for subperiod 1, as the aerial photographs were taken in January 1993, i.e. one year after TC Wasa occurred. Given that the time of readjustment of beach systems to intense TCs is known to be longer than one year (e.g. Ford and Kench, 2016; Duvat et al., 2017b), we can hypothesize 
that the coastal system had not completely recovered from the impacts of TC Wasa in 1993. All in all, sub-period 3 is the most appropriate for assessing the impacts of a high-energy event on coastal morphology, followed by sub-period 1. The other sub-periods (i.e. subperiods 2 and 4 ) are used to evaluate recovery, with sub-period 4 being the most appropriate one to do so, or to estimate changes under calmer conditions (i.e. without cyclonic events).

\section{Results}

\subsection{Base of the beach and beach loss (Fig. 7)}

At the multi-decadal scale (1982-2014), shoreline position mainly exhibited retreat. In fact, $57 \%$ of transects experienced erosion, while $36 \%$ were stable and only $3 \%$ advanced (SM table 4). Of note, $4 \%$ of transects were not documented (i.e. no data), due to land reclamation erroneously indicating shoreline advance. Average NSM was $-6.65 \mathrm{~m}$ and average EPR -0.21 $\mathrm{m} / \mathrm{y}$. NSM values ranged from -45.12 to $12.70 \mathrm{~m}$ (SM table 5). Spatial variability was relatively low (Fig. 7). Details about shoreline change at the sub-cell scale are provided in Supplementary Material (SM tables 6-10).

The comparison of the results obtained for the various sub-periods considered in this study reveals high short term (in several years) variability in shoreline position. During sub-period 1 (1982-1993), more than two thirds of transects remained relatively stable (72\%), while $15 \%$ experienced erosion and $9 \%$ showed accretion (with an additional $4 \%$ of no data), as indicated by an average NSM of $-0.86 \mathrm{~m}$ and an average EPR of $-0.08 \mathrm{~m} / \mathrm{y}$. Moreover, spatial variability was relatively high along the studied shoreline, with NSM values ranging from 16.47 to $23.14 \mathrm{~m}$. Over sub-period 2 (1993-2006), $49 \%$ and $46 \%$ of transects were stable and erosional, respectively. Average NMS was $-5.10 \mathrm{~m}$ and average EPR $-0.37 \mathrm{~m} / \mathrm{y}$. Only $2 \%$ of transects indicated shoreline advance (3\% of no data transects). NSM values ranged from 41.46 to $15.54 \mathrm{~m}$. Spatial variability was very low, erosion occurring in all sub-cells. During sub-period 3 (2006-2010), the base of the beach did not experience important planform changes, as $72 \%$ of transects remained stable, while 12\% of transects advanced and $9 \%$ receded (7\% of no data transects). Average NSM and EPR were 0.67 and $0.20 \mathrm{~m}$, respectively. Relatively high spatial variability was observed, with NSM values ranging from -14.15 to $19.37 \mathrm{~m}$. During sub-period 4 (2010-2014), stability was the main trend, with 77\% of transects exhibiting stability, while $15 \%$ and $2 \%$ showed erosion and accretion, respectively ( $6 \%$ of no data transects). Average NSM was $-1.33 \mathrm{~m}$, with values ranging from -11.58 to $7.01 \mathrm{~m}$, while average EPR was $-0.32 \mathrm{~m} / \mathrm{y}$. These results show significant temporal variability, with most sub-periods showing the predominance of stability (noted along around $75 \%$ of transects), while the 1993-2006 sub-period exhibited a high proportion (46\%) of erosional transects.

In places, severe erosion resulted in beach loss. Whereas all transects intersected beaches in 1982, 59 transects (7\%) distributed between five different sites indicated beach loss in 2014 (location and extent of beach loss are indicated on Fig. 7). The absence of a beach along the shoreline was still uncommon in 1993, as only 14 transects $(2 \%)$ were concerned. It increased importantly to reach 69 transects in 2006 (8\%), this latter date showing the highest value observed over the study period. The number of transects showing beach disappearance then slightly reduced to 65 transects (8\%) in 2010, and eventually to 59 transects in 2014. 


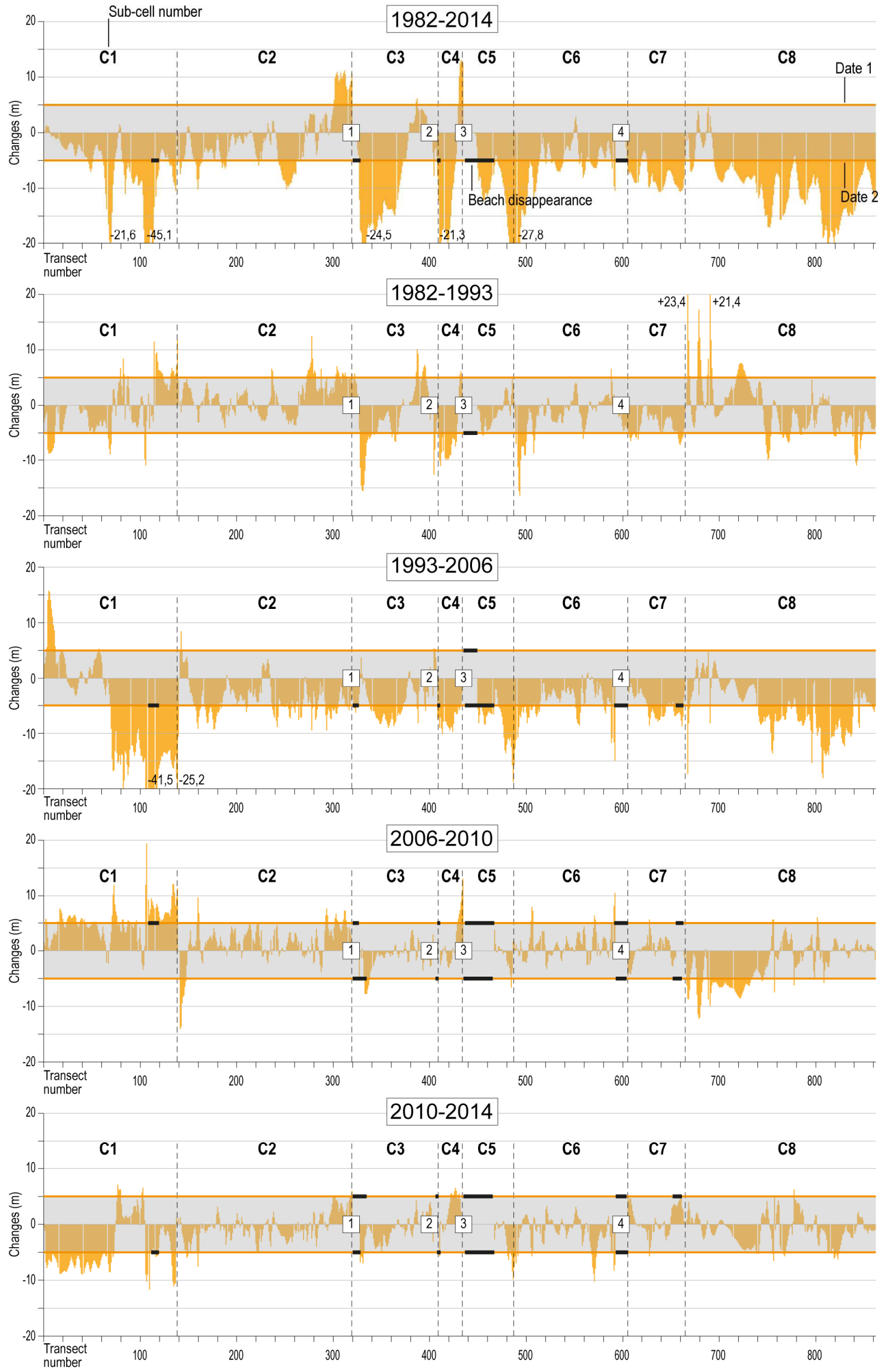


Fig. 7. Changes in the position of the base of the beach for the overall study period and sub-periods. Uncertainty is indicated by the greyed areas. The eight sub-cells are indicated. Sites showing beach loss are indicated by a black line. Numbers 1 to 4 refer to landmarks (cf. Fig.2). This chart highlights spatial-temporal variability. The results indicate moderate to high shoreline retreat at the multi-decadal scale (1982-2014) and within the 19932006 sub-period. The 1982-1993 sub-period is the one with the highest variability (accretion peaks vs. erosion peaks). The 2006-2010 sub-period shows a relatively stable shoreline, except in sub-cell 1, which experienced advance, and in sub-cell 8, which experienced retreat. Between 2010 and 2014, retreat was dominant in sub-cell 1 , while stability was dominant elsewhere. See text for detail.

\subsection{Stability line (Fig. 8)}

At the multi-decadal scale, stability was predominant (61\% of transects remained stable), followed by erosion (32\%), while only $7 \%$ of transects were accretionary. Average NSM was $-3.02 \mathrm{~m}$, with values ranging from -25.59 to $31.17 \mathrm{~m}$. Average EPR was $-0.09 \mathrm{~m} / \mathrm{y}$. Details about shoreline change at the sub-cell scale are provided in Supplementary Material (SM tables 6-10).

The comparison of the results obtained for the various sub-periods considered in this study reveals moderate short term (in several years) variability in shoreline position. Over subperiod 1 (1982-1993), stability was largely dominant (74\% of transects), while erosion and accretion represented $18 \%$ and $8 \%$ of transects, respectively. Average NSM was $-1.03 \mathrm{~m}$, with values ranging from -24.47 to $14.42 \mathrm{~m}$, and average EPR was $-0.09 \mathrm{~m} / \mathrm{y}$. On the sub-cell scale, spatial variability was high, with alternating erosion and accretion peaks (cf. Fig. 8). Over sub-period 2 (1993-2006), stability predominated (75\% of transects), followed by erosion (20\%), while only $5 \%$ of transects experienced shoreline advance. Average NSM was $-1.89 \mathrm{~m}$, with values ranging from -14.81 to $32.08 \mathrm{~m}$, and average EPR was $-0.14 \mathrm{~m} / \mathrm{y}$. Spatial variability was quite low (cf. Fig. 8). Over sub-period 3 (2006-2010), the stability line was predominantly stable ( $88 \%$ of transects), while $9 \%$ of transects experienced retreat and $1 \%$ advance ( $2 \%$ of no data transects). Average NSM was $-0.59 \mathrm{~m}$, with values ranging from -19.19 to $10.37 \mathrm{~m}$, and average EPR was $-0.05 \mathrm{~m} / \mathrm{y}$. Stability was the dominant pattern for the 8 sub-cells (cf. Fig. 8). Over sub-period 4 (2010-2014), 91\% of transects were stable, while $6 \%$ exhibited accretion and $3 \%$ showed erosion. Average NSM was $0.51 \mathrm{~m}$, with values ranging from -9.52 to $17.87 \mathrm{~m}$, and average EPR was $0.12 \mathrm{~m} / \mathrm{y}$. These results emphasize the prevalence of stability, despite variations in the proportion of stable transects from one subperiod to another.

\subsection{Human disturbances (Fig. 8)}

Except in the harbour area, no land reclamation was present in the study area in 1982. Land reclamation was first observed on the 1993 image near the harbour in sub-cell 5 (see Fig. 2B for sub-cell location), causing a $15 \mathrm{~m}$-advance of the stability line. At this time, another reclaimed plot was noted in sub-cell 3, to the west of the meteorological station (landmark No2), but it caused limited advance. Between 1993 and 2006, three additional reclaimed plots were built. The most extensive one, located in front of the high school (landmark No4), generated an advance of 10-15 m, while those which were built in front of the meteorological station (landmark No2) and near the river mouth in sub-cell 1 caused limited advance. Since 2006, no additional land reclamation works were undertaken. Of note, land reclamation caused systematic shoreline stabilization in concerned areas due to the erection of seawalls or rip-raps on the seaward edge of reclaimed plots. None of the 858 transects intersected coastal structures in 1982, as no longitudinal coastal structures or defences existed. In 1993, 69 
transects $(8 \%)$ intersected a fixed coastline, corresponding mostly to the reclaimed area near the harbour, where the beach disappeared. At this date, another part of the armoured shoreline was located in sub-cell 6 close to the high school, which protected buildings established on the upper beach. It is noteworthy that the number of transects intersecting armoured shoreline increased rapidly between 1993 and 2006, reaching 154 transects (18\%), equally distributed between all sub-cells, except sub-cell 8 . The number of transects corresponding to armoured shoreline remained stable until 2010 (158 transects), before exhibiting again a significant increase to reach 227 transects (26\%) in 2014. At this date, sub-cells 5 and 7 were almost entirely fixed, while the other sub-cells were still more natural. 

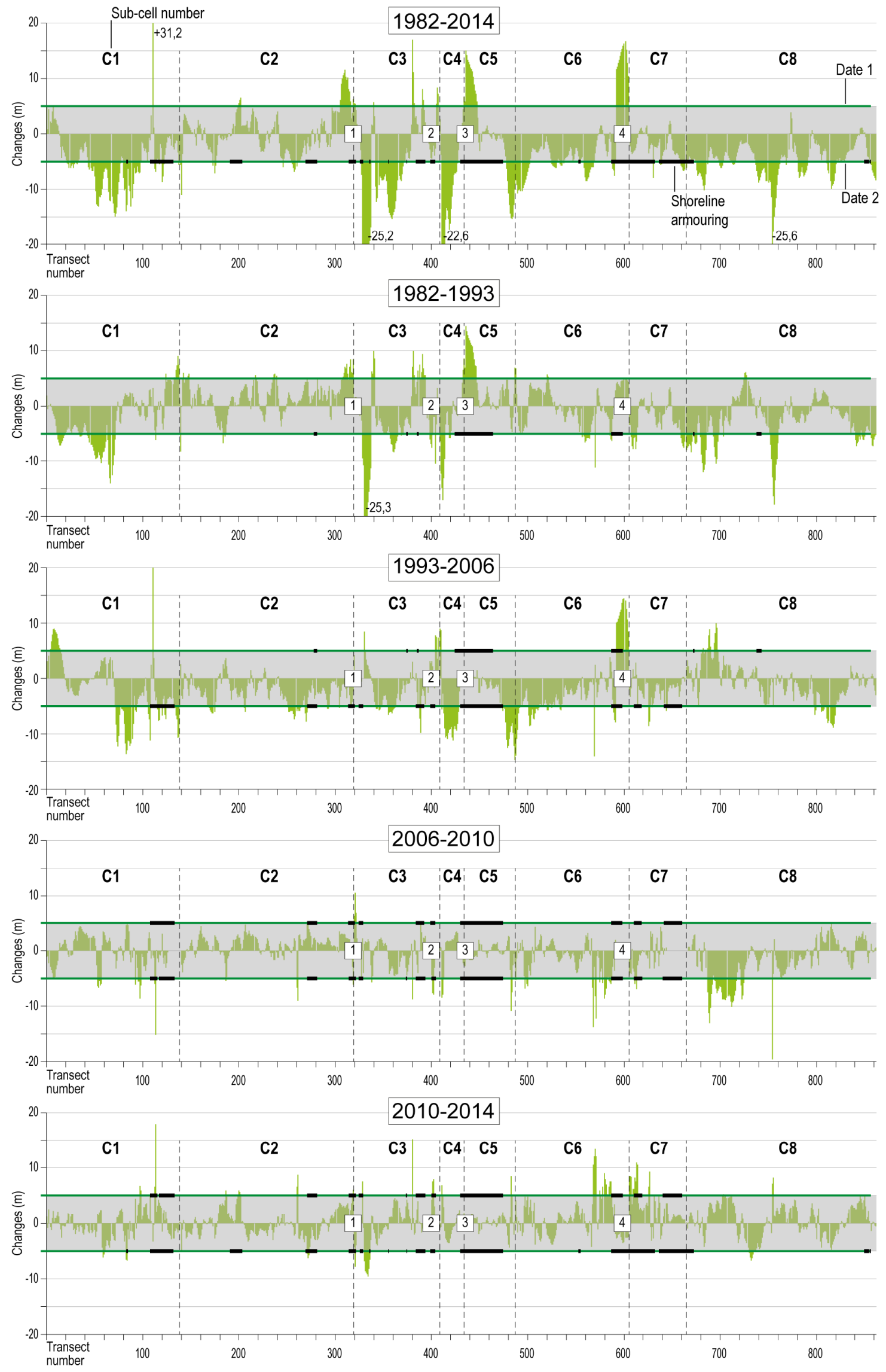
Fig. 8. Changes in the position of the stability line for the overall study period and sub-periods. Uncertainty is indicated by the greyed areas. The eight sub-cells are indicated. Nature of shoreline is also displayed: vegetation line is indicated by a thin green line whereas shoreline armouring is indicated by a thick black line. Numbers 1 to 4 refer to landmarks (cf. Fig.2). This shoreline proxy is logically more resistant to erosion, particularly during the sub-periods. At the multi-decadal scale, important changes occurred, with numerous cases of shoreline retreat interrupted in some places by shoreline advance. See text for more details.

\section{Discussion}

Results present the first detailed analysis of shoreline change on a mountainous tropical island in the central Pacific Ocean. Over the multi-decadal timeframe (1982-2014), the base of the beach predominantly exhibited retreat, which was observed along $57 \%$ of the shoreline. The stability line, was found to be more resistant to coastal erosion, as $61 \%$ of the shoreline remained stable while $32 \%$ experienced retreat. Results for the four sub-periods considered in this study showed high spatial-temporal variability. All in all, these results provide insights on the contribution of anthropogenic and climatic drivers to shoreline change.

\subsection{Human-induced shoreline change}

Human disturbances caused to coastal dynamics are a significant driver of shoreline positional change on the northern coast of Tubuai Island, especially at the multi-decadal scale. First, the most obvious modifications to the shoreline are related to land reclamation: between 1982 and 2014 , land reclamation caused the advance of $56 \%$ of the stability line transects. Second, the interception of the longshore sediment drift by human-built structures triggered major and contrasting changes around sediment sub-cell boundaries, causing updrift shoreline advance and downdrift shoreline retreat. Between 1982 and 2014 (Fig. 8), in 6 sub-cells out of 8, the base of the beach retreated at least at one of its extremities, exhibiting breaks between subcells reaching up to $30-40 \mathrm{~m}$ in some places. One representative example is found between sub-cells 2 and 3 (Figs. 4E and 5B), with NSM values of $+10 \mathrm{~m}$ and $-24.5 \mathrm{~m}$, respectively (see landmark No1). The interception of longshore sediment transport also drove, but to a lesser extent, stability line positional change, as shown by accelerated shoreline advance (until $10 \mathrm{~m}$ ) at the eastern part of sub-cell 2 (see landmark No1). As a result, the interception of the longshore sediment drift by human-built structures significantly contributes to explain the spatial variability observed between and within sub-cells: if these structures had not been built, it is likely that the base of the beach would have experienced moderate erosion and that the beach would have maintained along the entire shoreline. Third, shoreline armouring had contrasting effects, depending on the shoreline proxy considered: while it made the stability line more "resistant" (as illustrated by its response to TC Oli), it caused the retreat of the base of the beach, leading to beach loss in some places. The latter was documented by Romine and Fletcher (2012b) on Oahu, Hawaii, and by Jackson et al. (2012) in Puerto Rico. On Oahu, nearly all $(95 \%)$ of the documented beaches that were lost were fronting armoured shoreline. In Puerto Rico, Jackson et al. (2012) showed that beach width in front of seawalls was twice to four times narrower than on adjacent shoreline. "Passive" erosion was thus the main process identified on armoured coasts: "by limiting the ability of an eroding shoreline to migrate landward, coastal armouring on Oahu has contributed to narrowing and complete loss of many kilometres of beach" (Romine and Fletcher, 2012b). Another erosional pattern, i.e. 'increased 'flanking' erosion (accelerated shoreline retreat adjacent to armoured sections)", was observed on several beaches (Romine and Fletcher, 2012b). We came to the same conclusions on Tubuai, where anthropogenic disturbances explain beach loss. In fact, all 
of the 57 transects that exhibited beach loss in 2014 fronted either armoured shoreline, or land reclamation, or even were located downdrift transversal structures intercepting the longshore sediment drift (Table 4). At the multi-decadal scale, it is very likely that anthropogenic disturbances constitute the major driver of both the patterns and the extent of changes. Regional changes in sea level (+13 cm over the 1960-2012 period, according to Meyssignac et al., 2012), may thus be a secondary driver. Other studies came to the same conclusions (McLean and Kench, 2015; Duvat, 2018).

Table 4. Inventory of human disturbances involved in beach loss.

\begin{tabular}{|c|c|}
\hline Location of beach loss (also shown in Fig. 7) & Human disturbances \\
\hline Sub-cell 1 & Land reclamation + shoreline armouring \\
\hline Sub-cell 3 (landmark 1: city hall) & $\begin{array}{c}\text { Shoreline armouring }+ \text { interception of the longshore sediment } \\
\text { drift by the wharf }\end{array}$ \\
\hline $\begin{array}{l}\text { Limit between sub-cells } 3 \text { and } 4 \text { (landmark 2: } \\
\text { meteorological station) }\end{array}$ & Land reclamation + shoreline armouring \\
\hline Sub-cell 5 (near the harbour) & $\begin{array}{l}\text { Land reclamation }+ \text { shoreline armouring }+ \text { interception of the } \\
\text { longshore sediment drift by the wharf }\end{array}$ \\
\hline Sub-cell 6 (landmark 4: high school) & Land reclamation + shoreline armouring \\
\hline
\end{tabular}

\subsection{Contribution of cyclonic events to shoreline change}

Surprisingly, the contribution of cyclonic events to shoreline change appears to be moderate. This statement is illustrated by TC Oli, the event for which images fit the best. We thus assume that the shoreline changes observed between 2006 and 2010 were mainly due to this cyclone's impacts. Whereas it was the most severe cyclone ever recorded in French Polynesia (cf. Fig. 3 and Table 1), which generated massive damages (Etienne, 2012; Barriot et al., 2014; Laurent and Varney, 2014), impacts on shoreline position were relatively limited, as most transects for both proxies remained stable $(72 \%$ for the base of the beach and $88 \%$ for the stability line). It is likely that the waves generated by TC Oli were significantly attenuated by the presence of a combination of elements, which all together buffered them: the barrier and fringing reefs, the coastal vegetation and, in places, shoreline armouring. These results are in line with those from recent studies that highlighted the protective role of coral reefs (Van Zanten et al., 2014; Harris et al., 2018) for coastal systems and coastal human assets. Regarding the role of the coastal vegetation on Tubuai, its buffering function during TC Oli was observed by Etienne (2012), and noticeable despite the introduced character of most species. Importantly, TC Oli occurred in a context where almost $20 \%$ of the shoreline was armoured, even if coastal defences were not in a good state along the entire armoured shoreline. Beyond the overall stability of the stability line in the face of TC Oli, erosion occurred in the north-eastern part of the study area, i.e. at the western end of sub-cell 8 ( $\sim$ transects 680-720), where both shoreline proxies exhibited retreat (Fig. 7 and 8). This retreat was also observed during his post-cyclone field survey by Etienne (2012), who found higher values of horizontal retreat at Taahuaia compared to other locations. This area was the most exposed to the cyclonic waves that hit the island from the north-east (Fig. 6), without being attenuated by the presence of a fringing reef. Elsewhere, shoreline proxies did not indicate significant erosion. On the contrary, sub-cell 1, which is the most natural of all subcells, experienced an advance of the base of the beach (mean NSM of $+4.99 \mathrm{~m}$ ) that led to cyclone-induced beach reformation (transects 113-119, Fig. 7). This observation highlights the constructional effect of TCs, which may provide fresh material to sedimentary cells. These positive impacts of TCs on coastal morphology are reported in the literature (Duvat et al., 
2017b, 2017c; Kench and Mann, 2017; Vila-Concejo and Kench, 2017). Here, the advance of the base of the beach can be explained by the provision of both marine sediments by the coral reef (coral fragments were broken and transported to the coast by the cyclonic waves) and terrestrial sediments by rivers (many accretion peaks are situated at river mouths).

Although the 1993 aerial photograph was taken $~ 1$ year after TC Wasa hit Tubuai, the impacts of this TC on shoreline change were still visible on this photograph. First, marked erosional impacts were observed near the city hall (landmark No1). A sand spit that stretched eastward from the river mouth was nearly washed away (stability line retreat still reaching up to $-25 \mathrm{~m}$ one year after the event), either by the cyclonic waves, or by the river flow. Second, the base of the beach advanced on several shoreline sections in sub-cells 1 to 3 (Fig. 7). This must be noted, even though it is more difficult to assure that this change is attributable TC Wasa.

Beyond these specific observations, if we look at the general picture (Fig. 7), we note that sub-periods without cyclonic events or with one single cyclonic event occurring at the beginning of the sub-period (i.e. sub-period 2) are not associated with an advance of the base of the beach, but instead, with retreat (sub-period 2 again) or stability (sub-period 4), suggesting the constructional effect of TCs on Tubuai's coastal systems. To conclude, our results show that, except for a few cases (example of the abovementioned sand spit), TCs had a moderate influence on shoreline change on the northern coast of Tubuai. They generally caused a limited retreat of both the base of the beach and the stability line on the most exposed shoreline sections (i.e. Taahuaia), and a limited advance of the base of the beach on the most natural shoreline (i.e. sub-cell 1 at Mataura).

\subsection{Lessons learnt for coastal risk reduction and adaptation to climate change}

This study offers insights on how human and climate drivers can influence shoreline change. Furthermore, it offers the opportunity to analyse their interactions. First, it is interesting to note that every cyclone event contributed to the alongshore extension of coastal defences, especially Wasa and William (Viriamu, 2016, 2017). The extension of defences, which is easily detectable on aerial imagery, was realized by the public authorities to reduce the risks of damage to human assets. Along some shoreline sections, these structures were poorly designed and built, thereby contributing to cyclone-induced damage. In particular, during TC Oli, the rocks composing the rip-raps were thrown by the cyclonic waves into buildings (Etienne, 2012). Second, shoreline armouring generated "passive erosion", by preventing the coast from natural retreat, thereby contributing to beach loss, as at other sites (e.g. Romine and Fletcher, 2012b). As a result, it is likely that additional coastal defence structures will be built on Tubuai to combat erosion: this is a positive feedback loop. In addition, the human disturbances highlighted in this study probably explain why beach resilience to high-energy events is less effective along the urbanized coast of Tubuai than along the rest of its shoreline (e.g. hamlet of Anua on the western coast), as this had already been observed by Etienne (2012) in 2010.

The fact that human activities have destabilized the coastal sedimentary systems of Tubuai is likely to: (i) exacerbate the negative impacts of future TCs and TDs on both these systems and on the human society; (ii) prevent the morphological adjustment of the latter to accelerated sea-level rise. This problematic situation has already been described in capital, i.e. very populated, islands. For example, on the high mountainous island of Rarotonga (Cook Islands), 
De Scally (2014) showed that critical infrastructures, including most of safety centres, are highly-exposed to storm surges and marine inundation. Despite it is the capital island of the Austral Archipelago, Tubuai is a rural island having small population numbers $(2,322$ inhabitants in 2017) and a low population density ( 48 inhabitants $\left./ \mathrm{km}^{2}\right)$. In this context, the high exposure of human assets to coastal hazards is due to the development mode of this island. Since the main road, and later on water and electric facilities, were constructed very close to the shoreline, all houses and infrastructures were then established along the road, within a $200 \mathrm{~m}$-wide coastal strip. Because of their proximity to the shoreline, these human assets required protection from waves, which led to the construction of coastal defences and finally to the northern coast's destabilization.

Tubuai can be presented as a representative case of maladaptation ${ }^{3}$, where finally alternative solutions could be implemented. According to Magnan (2014), 'avoiding maladaptation is largely based on not repeating past and present mistakes (e.g. in spatial planning)', and 'support[ing] the protective role of ecosystems against current and future climate-related hazards'. On this point, our findings suggest that cyclone buffers, such as coral reefs and the coastal vegetation, have to be protected and strengthened to mitigate the destructive impacts of TCs on human assets, as they seem to still play a role, even where the coastal system has been altered by human activities. An increasing number of studies came to the same conclusion (Kaufman and Gallaher, 2011; Gracia et al., 2018; Harris et al., 2018), whereas others invited to be cautious. For instance, Feagin et al. (2010) denounced the misuse of bioshields policies ('vegetated barriers') since the Indian Ocean tsunami in 2004. First, because their efficiency is limited in the face of extreme events, and second, because bioshields policies have often led to biodiversity loss, as they mainly consisted of planting introduced trees (mainly Casuarina equisetifolia, as on Tubuai's coast) that finally replaced the native vegetation. However, here we advocate for the restoration of the native coastal vegetation, as this type of vegetation (e.g. Scaevola taccada) was found to be more resistant and resilient to TCs compared to introduced or mixed (i.e. native + introduced) species (e.g. Duvat et al., 2016; Duvat et al., 2017c). On Tubuai, a 60m-wide "free from building" coastal strip was recommended after $\mathrm{TC} \mathrm{Oli}$, in order to reduce the vulnerability of people and infrastructures to cyclonic events (Viriamu, 2017). This measure, which would imply the relocation of human assets in inner land areas, seems all the more appropriate that Tubuai's coastal plain is wide, exhibiting extended unbuilt areas for human asset relocation. Combining human assets' relocation with coastal buffer restoration would thus allow reducing both current and future risks under accelerated climate change.

\subsection{Limitations of the study and implications for small islands research}

The main limitations of this study relate to the availability of aerial and satellite imagery. As the oldest photographs were taken in 1982, the timescale considered is relatively short (i.e. 32 years), which is a limitation to capture long-term changes and to attribute change. However, even relatively short records were considered in previous studies (e.g. 19 years for Funafuti atoll, in Webb and Kench, 2010). More importantly, the images do not fit exactly with the dates of occurrence of cyclonic events, which limits our capacity to detect the contribution of

\footnotetext{
${ }^{3}$ Maladaptation is defined as 'a process that results in increased vulnerability to climate variability and change, directly or indirectly, and/or significantly undermines capacities or opportunities for present and future adaptation' (Magnan, 2014; Magnan et al., 2016).
} 
each cyclonic event to observed change. The best configuration was for TC Oli, and even though, we were not able to completely "isolate" this event from other influential factors, given that pre-cyclone image dated back to late 2006 (i.e. more than three years before the cyclone). With satellite imagery development, higher temporal resolution will enable to improve knowledge on TCs' impacts on coastal morphology and shoreline change.

In addition to multi-date image analysis, which allows capturing planform changes, beach monitoring, which has never been implemented in a remote island like Tubuai, would allow estimating changes in beach and barrier beach volume. This would allow better understanding cyclone- and human-induced changes at the coast, especially capturing the impacts of a given climate event on the sediment volume of a given sediment sub-cell. This seems all the more important that image availability severely constrains the assessment of cyclone-induced changes.

\section{Conclusions}

Based on available aerial imagery and fieldwork, this study assessed human- and climateinduced shoreline changes on a remote Pacific and mountainous island, i.e. Tubuai, in French Polynesia. Different time periods are considered, ranging from 3.5 to 32 years (1982-2014). At the multi-decadal scale, erosion was the dominant pattern when considering change in the position of the base of the beach. The other shoreline proxy, the stability line, was found to be more resistant to coastal erosion. Superimposing these observations with data on human development suggests the primary influence of the latter on shoreline change, as significant changes can be explained directly or indirectly by human activities, especially the fragmentation of the initial sedimentary cell into several sub-cells by transversal structures, land reclamation and shoreline armouring. Focusing on sub-periods, we found a high variability in shoreline behaviour. In particular, the 2006-2010 sub-period enabled to capture the impacts of TC Oli (February 2010), one of the strongest cyclones ever recorded in the Central Pacific region. Surprisingly, most of the transects experienced stability, probably due to the presence of cyclone buffers (notably, the barrier and fringing reefs) associated with shoreline armouring. Importantly, along the "natural" shoreline, the cyclonic waves had a constructional effect, causing an advance of the base of the beach and even beach reformation in places, due either to reef-to-island sediment transport or to the provision of sediments by rivers.

Despite some limitations (limited image availability, lack of topographic data), the present study, by documenting past shoreline changes and their drivers, can be a first step towards improved coastal management. For instance, its outcomes reinforce the idea that TCs' impacts on human assets are exacerbated by local human disturbances, which weaken natural buffers, such as barrier beaches and vegetated back-beaches. Based on these observations, this case study advocates for the combination of human assets' relocation and the restoration of cyclone buffers to reduce current and future risks under accelerated climate change. 


\section{References}

Barriot, J., Serafini, J., Maamaatuaiahutapu, K., Sichoix, L., 2016. The Island of Tubuai (French Polynesia) Landfall of Cyclone Oli on the 5th of February. Open Access Libr. J. 3, 9. doi:10.4236/oalib.1102615

Bird, E. C. F., 1985. Coastline changes; A Global Review. Wiley, Chichester

Bheeroo, R.A., Chandrasekar, N., Kaliraj, S., Magesh, N.S., 2016. Shoreline change rate and erosion risk assessment along the Trou Aux Beaches-Mont Choisy beach on the northwest coast of Mauritius using GIS-DSAS technique. Environ. Earth Sci. 75, 1-12. doi:10.1007/s12665-016-5311-4

Cooper, J.A.G., Pilkey, O.H., 2012. Pitfalls of Shoreline Stabilization: Selected Case Studies. Springer, London.

De Scally, F.A., 2014. Evaluation of storm surge risk: A case study from Rarotonga, Cook Islands. Int. J. Disaster Risk Reduct. 7, 9-27. doi:10.1016/j.ijdrr.2013.12.002

Duvat, V.K.E., Magnan, A.K., Etienne, S., Salmon, C., Pignon-Mussaud, C., 2016. Assessing the impacts of and resilience to Tropical Cyclone Bejisa, Reunion Island (Indian Ocean). Natural Hazards 83, 601-640.

Duvat, V.K.E., Pillet, V., 2017. Shoreline changes in reef islands of the Central Pacific: Takapoto Atoll, Northern Tuamotu, French Polynesia. Geomorphology 282, 96-118. doi:10.1016/j.geomorph.2017.01.002

Duvat, V.K.E., Magnan, A.K., Wise, R.M., Hay, J.E., Fazey, I., Hinkel, J., Stojanovic, T., Yamano, H., Ballu, V., 2017a. Trajectories of exposure and vulnerability of small islands to climate change. Wiley Interdiscip. Rev. Clim. Chang. 8, 1-14. doi:10.1002/wcc.478

Duvat, V.K.E., Salvat, B., Salmon, C., 2017b. Drivers of shoreline change in atoll reef islands of the Tuamotu Archipelago, French Polynesia. Glob. Planet. Change 158, 134-154. doi:10.1016/j.gloplacha.2017.09.016

Duvat, V.K.E., Volto, N., Salmon, C., 2017c. Impacts of category 5 tropical cyclone Fantala (April 2016) on Farquhar Atoll, Seychelles Islands, Indian Ocean. Geomorphology 298, 41-62. doi:10.1016/j.geomorph.2017.09.022

Duvat, V.K.E., 2018. A global assessment of atoll island planform changes over the past decades. WIREs CC. doi: 10.1002/wcc.557

Etienne, S., 2012. Marine inundation hazards in French Polynesia: geomorphic impacts of Tropical Cyclone Oli in February 2010. Geol. Soc. London, Spec. Publ. 361, 21-39. doi:10.1144/SP361.4

Feagin, R.A., Mukherjee, N., Shanker, K., Baird, A.H., Cinner, J., Kerr, A.M., Koedam, N., Sridhar, A., Arthur, R., Jayatissa, L.P., Lo Seen, D., Menon, M., Rodriguez, S., Shamsuddoha, M., Dahdouh-Guebas, F., 2010. Shelter from the storm? Use and misuse of coastal vegetation bioshields for managing natural disasters. Conserv. Lett. 3, 1-11. doi:10.1111/j.1755-263X.2009.00087.x

Fletcher, C.H., Mullane, R.A., Richmond, B.M., 1997. Beach Loss Along Armored Shorelines on Oahu, Hawaiian Islands. J. Coast. Res. 13, 209-215.

Ford, M., Kench, P.S., Formation and adjustment of typhoon-impacted reef islands interpreted 
from remote imagery: Nadikdik Atoll, Marshall Islands. Geomorphology 214, 216-222. doi: 10.1016/j.geomorph.2014.02.006

Gracia, A., Rangel-Buitrago, N., Oakley, J., Williams A.T., 2018. Use of ecosystems in coastal erosion management. Ocean Coast. Manag. 156, 277-289. doi:10.1016/j.ocecoaman.2017.07.009

Hapke, C.J., Reid, D., Richmond, B.M., Ruggiero, P., List, J., 2006. National assessment of shoreline change, Part 3: Historical shoreline change and associated coastal land loss along sandy shorelines of the California coast.

Hapke, C.J., Kratzmann, M.G., Himmelstoss, E.A., 2013. Geomorphic and human influence on large-scale coastal change. Geomorphology 199, 160-170. doi:10.1016/j.geomorph.2012.11.025

Harris, D.L., Rovere, A., Casella, E., Power, H., Canavesio, R., Collin, A., Pomeroy, A., Webster, J.M., Parravicini, V., 2018. Coral reef structural complexity provides important coastal protection from waves under rising sea levels. Sci. Adv. 4, 1-8. doi:10.1126/sciadv.aao4350

Inman, D.L., 2005. Littoral Cells, in: Schwartz, M.L. (Ed.), Encyclopedia of Coastal Science. Springer Netherlands, Dordrecht, pp. 594-599. doi:10.1007/1-4020-3880-1_196

Kench, P.S., Mann, T., 2017. Reef Island Evolution and Dynamics: Insights from the Indian and Pacific Oceans and Perspectives for the Spermonde Archipelago. Front. Mar. Sci. 4. doi:10.3389/fmars.2017.00145

Jackson C.W., Bush D.M., Neal W.J., 2012. Documenting Beach Loss in Front of Seawalls in Puerto Rico: Pitfalls of Engineering a Small Island Nation Shore. In: Cooper J., Pilkey O. (eds) Pitfalls of Shoreline Stabilization. Coastal Research Library, vol 3. Springer, Dordrecht

Kaufman, A., Gallaher, T., 2011. Effectiveness of Vegetation for Mitigating the Coastal Impact Due to Storm Surge and Tsunamis. University of Hawaii at Manoa, Department of Tropical Plant and Soil Sciences.

Laurent, V., Varney, P., 2014. Historique des cyclones de Polynésie française de 1831 à 2010. Météo France.

Laurent, V., 2015. Le climat aux Australes. In : Salvat B., Bambridge T., Tanret D. Petit J., 2015. Environnement marin des îles Australes, Polynésie française. Institut Récifs Coralliens Pacifique, CRIOBE et The Pew Charitable Trusts Polynésie française. ISBN 978-2-905630-08-7, EAN 9782905630087. Polynésie française, Tahiti, p. 40-49.

Lecacheux, S., Bulteau, T., Pedreros, R., Delvallée, E., Paris, F., 2013. Projet ARAI 3 : Evaluation probabiliste des houles et des surcotes cycloniques en Polynésie française. Rapport BRGM/RP-61888-FR.

Luijendijk, A., Hagenaars, G., Ranasinghe, R., Baart, F., Donchyts, G., Aarninkhof, S., 2018. The State of the World's Beaches. Sci. Rep. 1-11. doi:10.1038/s41598-018-24630-6

Magnan, A., 2014. Avoiding maladaptation to climate change: towards guiding principles. S.a.p.i.en.s 7, 1-11.

Magnan, A. K., Schipper, E. L. F., Burkett, M., Bharwani, S., Burton, I., Eriksen, S., Gemenne, F., Schaar, J., Ziervogel, G., 2016. Addressing the risk of maladaptation to 
climate change. WIREs Climate Change 7, 646-65. doi.10.1002/wcc.409

McLean, R., Kench, P., 2015. Destruction or persistence of coral atoll islands in the face of 20th and 21st century sea-level rise? WIREs CC. doi:10.1002/wcc.350

Meyssignac, B., Becker, M., Llovel, W., Cazenave, A., 2012. An assessment of twodimensional past sea level reconstructions over 1950-2009 based on tide-gauge data and different input sea level grids. Surveys in Geophysics 33, 945-972. doi:10.1007/s10712011-9171-X

Nunn, P.D., Kumar, L., Eliot, I., McLean, R.F., 2016. Classifying Pacific islands. Geosci. Lett. 3, 7. doi:10.1186/s40562-016-0041-8

Nurse, L.A., McLean, R.F., Agard, J., Briguglio, L.P., Duvat-Magnan, V., Pelesikoti, N., Tompkins, E., Webb, A., 2014b. Small islands. Clim. Chang. 2014 Impacts, Adapt. Vulnerability. Part B Reg. Asp. Contrib. Work. Gr. II to Fifth Assess. Rep. Intergov. Panel Clim. Chang. 1613-1654. doi:10.2134/jeq2008.0015br

Pelling, M., Uitto, J.I., 2001. Small island developing states: Natural disaster vulnerability and global change. Environ. Hazards 3, 49-62. doi:10.3763/ehaz.2001.0306

Ranasinghe, R., 2016. Assessing climate change impacts on open sandy coasts: A review. Earth-Science Reviews 160, 320-332. doi:10.1016/j.earscirev.2016.07.011

Rankey, E.C., 2011. Nature and stability of atoll island shorelines: Gilbert Island chain, Kiribati, equatorial Pacific. Sedimentology 58, 1831-1859. doi:10.1111/j.13653091.2011.01241.x

Romine, B.M., Fletcher, C.H., 2012a. A Summary of Historical Shoreline Changes on Beaches of Kauai, Oahu, and Maui, Hawaii. J. Coast. Res. 605-614. doi:10.2112/JCOASTRES-D-11-00202.1

Romine B.M., Fletcher C.H., 2012b. Armoring on Eroding Coasts Leads to Beach Narrowing and Loss on Oahu, Hawaii. In: Cooper J., Pilkey O. (eds) Pitfalls of Shoreline Stabilization: Selected Case Studies. Coastal Research Library, vol 3. Springer, Dordrecht

Scandurra, G., Romano, A.A., Ronghi, M., Carfora, A., 2018. On the vulnerability of Small Island Developing States: A dynamic analysis. Ecol. Indic. 84, 382-392. doi:10.1016/J.ECOLIND.2017.09.016

Thieler, E.R., Himmelstoss, E.A., Zichichi, J.L., Ergul, A., 2017. Digital Shoreline Analysis System (DSAS) version 4.0-An ArcGIS extension for calculating shoreline change (ver. 4.4, July 2017). U.S. Geological Survey, Open-File Report 2008-1278

Viriamu, T., 2016. Etude de la vulnérabilité de l'île de Tubuai face aux événements cycloniques : les cas de Wasa (1991), William (1995) et Oli (2010). Rapport de stage de Master 1. Université de la Rochelle

Viriamu, T., 2017. Trajectoire de vulnérabilité et adaptation face aux risques liés à la mer dans un contexte de changement climatique : le cas de Tupua'i, Polynésie française. Rapport de stage de Master 2. Université de la Rochelle

Van Zanten, B.T., Van Beukering, P.J.H., Wagtendonk, A.J., 2014. Coastal protection by 
coral reefs: A framework for spatial assessment and economic valuation. Ocean Coast. Manag. 96, 94-103. doi:10.1016/j.ocecoaman.2014.05.001

Van Wynsberge, S., Andréfouët, S., Gaertner-Mazouni, N., Wabnitz, C.C.C., Menoud, M., Le Moullac, G., Levy, P., Gilbert, A., Remoissenet, G., 2017. Growth, survival and reproduction of the giant clam tridacna maxima (Röding 1798, Bivalvia) in two contrasting lagoons in French Polynesia. PLoS One 12, 1-20. doi:10.1371/journal.pone.0170565

Vila-Concejo, A., Kench, P., 2017. Storms in Coral Reefs, in: Ciavola, P., Coco, G. Coastal Storms: Processes and Impacts, John Wiley \& Sons Ltd. 127-149. doi:10.1002/9781118937099.ch7

Webb, A.P., Kench, P.S., 2010. The dynamic response of reef islands to sea-level rise: Evidence from multi-decadal analysis of island change in the Central Pacific. Glob. Planet. Change 72, 234-246. doi:10.1016/j.gloplacha.2010.05.003

Yates, M.L., Le Cozannet, G., Garcin, M., Salaï, E., Walker, P., 2013. Multidecadal Atoll Shoreline Change on Manihi and Manuae, French Polynesia. J. Coast. Res. 289, 870882. doi:10.2112/JCOASTRES-D-12-00129.1 